\title{
Artikel
}

\section{De gedoogplicht onder de Omgevingswet: een (ver)nieuw(d) grondbeleidsinstrument}

\author{
Mr. A.P. (Arjan) van Delden en mr. S.A. (Sheila) van Gemeren*
}

\section{Inleiding}

Met de inwerkingtreding van de Omgevingswet (Ow) komen de Waterwet ${ }^{1}$ en de Belemmeringenwet Privaatrecht $(\mathrm{BP})^{2}$ te vervallen. De mogelijkheid die deze wetten aan het bevoegd gezag bieden om bij beschikking een gedoogplicht op te leggen om werken en werkzaamheden te gedogen die de vrije gebruiksmogelijkheden van een perceel belemmeren, blijft onder de Ow aanwezig en wordt zelfs verruimd. Die verruiming leidt er onder andere toe dat vormen van meervoudig grondgebruik die onder het huidige wettelijke regime uitsluitend door middel van onteigening kunnen worden afgedwongen, na de inwerkingtreding van de Ow tot stand kunnen komen zónder onteigening, maar met een bij beschikking opgelegde gedoogplicht.

In deze bijdrage vergelijken wij het huidige wettelijke stelsel met dat van de Ow. Allereerst gaan we in op de verruimde bevoegdheden en de gewijzigde procedureregels. Vervolgens bespreken we de verhouding tussen onteigenen en het opleggen van een gedoogplicht: welke omstandigheden bepalen voor welk instrument moet worden gekozen? Die keuze heeft niet alleen consequenties voor de privaatrechtelijke rechtstoestand, maar ook voor de afwikkeling van schade. We gaan in op het wettelijke systeem van schadevergoeding bij een op- gelegde gedoogplicht en vergelijken dit met de schadeloosstellingssystematiek uit het onteigeningsrecht. Tevens gaan we in op de nieuwe wettelijke regeling op basis waarvan gedoogplichtigen in sommige gevallen een gebruiksvergoeding kunnen verlangen. We bespreken deze nieuwe wettelijke regeling en de mogelijke consequenties daarvan voor de inhoud van het minnelijk overleg, dat altijd gevoerd moet worden om te trachten afspraken te maken ter voorkoming van een publiekrechtelijke gedoogplicht. We ronden af met enkele conclusies en aanbevelingen voor de praktijk.

Qua terminologie haken we in dit artikel aan bij twee belangrijke begrippen. Onder 'initiatiefnemer' wordt in de Ow verstaan 'degene onder wiens verantwoordelijkheid een werk van algemeen belang waarvoor een gedoogplicht is opgelegd, tot stand wordt gebracht of wordt opgeruimd'. Een initiatiefnemer is bijvoorbeeld de netbeheerder die de gedoogbeschikking aanvraagt en (nadat is beschikt) de houder van de gedoogbeschikking is. Onder 'rechthebbende' wordt verstaan 'degene die enig recht heeft op de onroerende zaak waarin, waarop, waarboven of waaronder' een gedoogplicht van toepassing is. ${ }^{3}$ Dat zijn bijvoorbeeld de grondeigenaren en andere partijen die een gebruiksrecht hebben, zoals erfpachters, pachters of huurders. 


\section{Gedoogplichten: nu en straks}

\subsection{Huidige wetgeving versus Omgevingswet}

Naast de BP gaan ook de Waterwet en andere sectorale wetten geheel of gedeeltelijk op in de Ow. ${ }^{4}$ Weliswaar is straks sprake van een meer uniforme wettelijke regeling, maar de systematiek van de Ow brengt helaas wel met zich dat voor de verschillende relevante regels alsnog flink moet worden gebladerd (of gescrold).

In deze paragraaf schetsen we de relevante bepalingen zoals deze worden opgenomen in de Ow en vergelijken we deze met de huidige systematiek.

Onder het huidige recht worden de meeste gedoogbeschikkingen verleend op grond van de BP en hebben de meeste bestuursrechtelijke procedures over gedoogbeschikkingen betrekking op die wet. In het navolgende vergelijken we de systematiek van de regeling van gedoogplichten onder de Ow dan ook primair met de systematiek van de BP. Waar dat nuttig is, maken we een vergelijking met de Waterwet.

Hoofdstuk 10 Ow vormt de basis voor de nieuwe wettelijke regeling. In afdeling 15.2 zijn specifiek voor gedoogplichten regels opgenomen over vergoeding van schade. In aanvulling daarop is als gevolg van een amendement in art. 13.3e Ow (onderdeel van afdeling 13.2 over 'vergoeding en verhaal van kosten') een regeling geïntroduceerd voor een gebruiksvergoeding waarop een rechthebbende zich in een beperkt aantal gevallen kan beroepen. ${ }^{5}$ In paragraaf 16.3.7 (onderdeel van afdeling 16.2) zijn ten slotte procedureregels opgenomen die van toepassing zijn op de voorbereiding van gedoogbeschikkingen.

\subsection{Gedoogplichten van rechtswege}

De huidige wetgeving kent een onderscheid tussen gedoogplichten van rechtswege en bij beschikking op te leggen gedoogplichten. Dat onderscheid blijft onder de Ow gehandhaafd. ${ }^{6}$

Gedoogplichten van rechtswege kunnen minder ingrijpend zijn dan bij beschikking opgelegde gedoogplichten. Dat neemt niet weg dat ook gedoogplichten die van rechtswege gelden als ingrijpend kunnen worden ervaren. Denk aan gedoogplichten die verband houden met metingen, het aanbrengen van tekens, een bevoegdheid tot betreding voor onderzoek of maatregelen ter beheer van zwemwater alsook met tijdelijke graaf-, onderhouds- en herstelwerkzaamheden.
2.3 Bij beschikking op te leggen gedoogplichten Net als onder de BP en de Waterwet kunnen onder de Ow gedoogplichten die langduriger en/of permanenter ingrijpen op het (eigendoms)recht van de rechthebbende, uitsluitend worden opgelegd bij beschikking. Gedoogbeschikkingen kunnen bijvoorbeeld worden verleend voor de aanleg en instandhouding van (bovengrondse of ondergrondse) hoogspanningsverbindingen, infrastructurele werken, waterstaatswerken, gasleidingen, afvalwaterleidingen of windmolenparken en voor allerlei bijkomende (nuts)voorzieningen. Dergelijke werken belemmeren het gebruik van de grond permanent. Daarnaast kan een bij beschikking opgelegde gedoogplicht als grondslag dienen voor bijbehorende tijdelijke belemmeringen, zoals het gebruiken van gronden als werkterrein.

\section{- Werk en initiatiefnemer}

Onder de BP kunnen het Rijk, provincies en waterschappen als initiatiefnemers voor elk willekeurig netwerk (rechtstreeks) om een gedoogbeschikking verzoeken. Andere initiatiefnemers moeten - in wettelijk bepaalde gevallen - éérst een concessieverlenings- en/of erkenningsprocedure doorlopen. Uiteindelijk kan dat leiden tot verkrijging van een concessie- en/of erkenningsbesluit. Daarmee wordt het algemeen belang erkend. ${ }^{7}$ Dat is bijvoorbeeld nodig als:

1. het werk wordt ondernomen door een gemeente (in welk geval alleen een erkenningsbesluit nodig is); of

2. een vennootschap de initiatiefnemer is en het openbaar nut van het netwerk niet blijkt uit de wet of uit een eerder verleende concessie of erkenning van openbaar belang (in welk geval een concessie- én een erkenningsbesluit nodig zijn). ${ }^{8}$

Een wettelijke grondslag voor het openbaar nut van een werk volgt bijvoorbeeld uit de Elektriciteitswet 1998, de Warmtewet of de Gaswet. Als een vennootschap een openbaar werk wil aanleggen, waarvan het openbaar nut uit de wet blijkt (bijvoorbeeld een hoogspanningsnetwerk), kan de conclusie zijn dat geen concessie- en/of erkenningsbesluit nodig is. ${ }^{9}$ Of een initiatiefnemer rechtstreekse toegang tot de BP heeft, of dat een concessie- en/of erkenningsbesluit nodig zijn, moet van geval tot geval worden beoordeeld.

Onder de Ow wordt de wettelijke regeling een stuk overzichtelijker en worden de procedureregels sterk vereenvoudigd. Zo wordt afscheid genomen van het erkennings- en/of concessievereiste en wordt aansluiting gelokaal spoor, Wet luchtvaart, Elektriciteitswet 1998 en onteigeningswet. De Telecommunicatiewet blijft behouden. De daarin opgenomen wettelijke gedoogplichten van rechtswege (met een daaraan verbonden verplichting om overeenstemming te bereiken over het tijdstip en de plaats van de werken en werkzaamheden) blijven dus van kracht. Zie art. 5.2 e.v. Telecommunicatiewet.

5 Kamerstukken II 2018/19, 34 986, nr. 50 (amendement Bisschop/Ronnes).

6 In een enkel uitzonderlijk geval is een gedoogplicht van rechtswege ver vangen door een bevoegdheid bij beschikking een gedoogplicht op te leggen. Zie art. 10.19a en 10.20 Ow.

on concessiebesluit kan door het bevoegd gezag ook wee worden ingetrokken, zie Koninklijk Besluit van 20 januari 2021, Stcrt. 2021, 6491 (Intrekking van de erkenning van het openbaar belang van werken tot de aanleg en instandhouding van een ondergrondse hoogspanningskabel tussen de Clauscentrale in Maasbracht in Nederland en het schakelstation van Eyck in Ophoven in België).

8 Rijkswaterstaat, Leidraden. De gedoogplichtprocedure ingevolge de Belemmeringenwet Privaatrecht (Bestuurlijk Juridische KaderReeks), Utrecht 2008, p. 37.

9 Rijkswaterstaat 2008, p. 37. 
zocht bij het procesrecht van de Algemene wet bestuursrecht (Awb).

Art. 10.13 tot en met 10.20 Ow sommen categorieën van gevallen op ten behoeve waarvan bij beschikking gedoogplichten kunnen worden opgelegd. Voor deze gevallen is het algemeen belang door de Ow van rechtswege gegeven. In deze categorieën van gevallen hoeft de initiatiefnemer het algemeen belang dus niet te motiveren omdat de wet daar al in voorziet. Het gaat onder andere om infrastructuur, water, hoogspanningsverbindingen, windparken van ten minste $5 \mathrm{MW},{ }^{10}$ gasleidingen, mijnbouwwerken, kernenergiewerken, warmtenetten en rioolpersleidingen, alsmede diverse onderzoeken op het terrein van ontgrondingen, luchtverontreiniging en archeologie.

Art. 10.21 Ow introduceert een vangnetbepaling. Op basis daarvan kan de minister aan een rechthebbende een gedoogplicht opleggen voor een werk van algemeen belang dat niet valt onder de in art. 10.13 tot en met 10.20 Ow opgenomen limitatieve opsomming. ${ }^{11}$ Hier wordt dus een algemene bevoegdheid geïntroduceerd voor het opleggen van gedoogplichten. Voorwaarde is, naar de letter van de wet, dat 'het belang van de openbare veiligheid, het belang van het beschermen van de fysieke leefomgeving, zwaarwegende economische belangen of zwaarwegende andere maatschappelijke belangen dit rechtvaardigen'. De minister zal in een beschikking ex art. 10.21 Ow deugdelijk moeten motiveren dat aan deze voorwaarde is voldaan. Met andere woorden: er moet van geval tot geval worden gemotiveerd dat sprake is van een zwaarwegend belang dat tot de oplegging van een gedoogplicht noodzaakt, waarbij de grondslag niet gelegen kan zijn in de limitatieve opsomming van art. 10.13 tot en met $10.20 \mathrm{Ow}$, die aan de vangnetbepaling ex art. 10.21 Ow voorafgaat.

\section{- $\quad$ Bevoegd gezag}

Onder de BP is de Minister van Verkeer en Waterstaat (thans: de Minister van Infrastructuur en Waterstaat; hierna: de minister) bevoegd gedoogbeschikkingen te verlenen. Gedoogverzoeken worden behandeld door Rijkswaterstaat Corporate Dienst (RWS CD) en moeten aldus daar worden ingediend. RWS CD heeft - als onderdeel van de Bestuurlijk Juridische KaderReeks - twee leidraden gepubliceerd: voor het opstellen van de stukken en het samenstellen van het dossier en voor de gedoogplichtprocedure op grond van de BP. Verder is bij RWS CD een informatiepakket op te vragen, dat onder meer modelstukken en voorbeelden bevat.

Ook onder de Ow is voor het merendeel van de gevallen de minister bevoegd, maar voor bijvoorbeeld beheer, aanleg of wijziging van waterstaatswerken is het dagelijks bestuur van het beherende waterschap bevoegd

10 Thans nog geregeld in art. 9g Elektriciteitswet 1998. Vgl. ABRvS 18 december 2019, ECLI:NL:RVS:2019:4326 (gedoogbeschikking Windmolen Park Zeewolde)

11 Daardoor is het wetsvoorstel toekomstbestendig en kan worden geanticipeerd op technologische en innovatieve ontwikkelingen. (zoals nu onder de Waterwet). Gedoogverzoeken op grond van de Ow waarvoor de minister bevoegd gezag is, zullen in de praktijk wederom door RWS CD worden behandeld. Wij verwachten dat een geactualiseerd en op de Ow afgestemd informatiepakket wordt gepubliceerd zodra de Ow in werking is getreden.

\section{- $\quad$ Rechtsgevolgen gedoogplicht}

Voorafgaand aan een gedoogverzoek moet een initiatiefnemer een voldoende serieuze ('redelijke') poging ondernemen om afspraken met rechthebbenden te maken over het gebruik van hun gronden. Als minnelijke overeenstemming wordt bereikt, kan het werk zonder gedoogplicht op rechtmatige wijze worden aangelegd en in stand gehouden.

Op grond van art. 5:20 lid 2 van het Burgerlijk Wetboek (BW) is een net van kabels en leidingen (bestemd voor het transport van vaste, vloeibare of gasvormige stoffen, energie of informatie) een zelfstandige onroerende zaak. Art. 5:20 lid 2 BW vormt een uitzondering op de hoofdregel van lid 1 , waarin de leer van de verticale natrekking is vastgelegd. Natrekking door de onder- of bovengrond op grond van art. 5:20 lid $1 \mathrm{BW}$ is dus bij een net van kabels en leidingen niet aan de orde. In tegenstelling tot wat vaak wordt verondersteld, is het maken van afspraken over de aanleg en instandhouding van een net van kabels en leidingen dus niet nodig om de eigendomsverhoudingen te regelen. Dat neemt niet weg dat in de praktijk in het minnelijk overleg ter voorkoming van een gedoogbeschikking door initiatiefnemers vrijwel altijd 'zakelijk-rechtovereenkomsten' worden aangeboden, waarin afspraken staan over de vestiging van opstalrechten, erfdienstbaarheden en kwalitatieve verplichtingen. ${ }^{12}$ Om deze rechtsfiguren derdenwerking te laten hebben, moeten zij worden gevestigd door het laten opmaken van een notariële akte, die vervolgens moet worden ingeschreven in de openbare registers van het Kadaster. ${ }^{13}$

Evenals een opstalrecht rust een gedoogplicht op een onroerende zaak. De gedoogbeschikking is in de huidige wetgeving de publiekrechtelijke evenknie van het opstalrecht. Onder de Ow wordt dit niet anders. In de gedoogbeschikking wordt aansluiting gezocht bij de aanduiding van perceelnummers in het Kadaster. De opgelegde gedoogbeschikking wordt bovendien ook ingeschreven in het Kadaster en is kenbaar uit de eigendomsinformatie. Een gedoogbeschikking kan slechts worden opgelegd c.q. ingeschreven op een geheel kadastraal perceel. Uit de beschikking blijkt vervolgens welk perceelgedeelte daadwerkelijk met de gedoogplicht is bezwaard. Verder blijkt (de omvang van) het werk uit de bij de beschikking behorende tekeningen

12 Over het verschil en de voor- en nadelen van deze rechtsfiguren heeft Sheila van Gemeren eerder een blog geschreven: www.linkedin.com/ pulse/aanleg-van-een-kabel-en-leidingnet-alternatieven-voor-vangemeren/.

13 Zie art. 3:89 jo. art. 3:98 BW; maar ook B.A.M. Janssen, Wie heeft de leiding? De eigendom van kabel- en leidingnetten (Recht en Praktijk, nr. VG1; diss. Utrecht), Deventer: Kluwer 2010. 
(bestaande uit een overzichtstekening, een grondtekening en profieltekeningen).

Bij een opstalrecht rust op de rechthebbende een duldplicht. Materieel is de publiekrechtelijke gedoogplicht niet of nauwelijks van deze privaatrechtelijke zakenrechtelijke duldplicht te onderscheiden. Net zoals het geval zou zijn indien het werk zou zijn aangelegd en in stand gehouden op basis van gevestigde zakelijke rechten, is het te gedogen werk als zodanig eigendom van de initiatiefnemer.

In art. 9g Elektriciteitswet 1998 is volledigheidshalve vastgelegd dat de in art. 5:20 lid 2 BW beschreven uitzondering op de leer van de verticale natrekking van overeenkomstige toepassing is op openbare werken van algemeen nut waarvoor een gedoogplicht geldt als bedoeld in de BP, ook voor zover dat werken betreft die niet met zoveel woorden zijn genoemd in art. 5:20 lid 2 BW. ${ }^{14}$ $\mathrm{Na}$ de inwerkingtreding van de Ow vervangt art. 10.28 Ow art. 9g Elektriciteitswet 1998 door art. 5:20 lid 2 BW van overeenkomstige toepassing te verklaren op alle werken van algemeen belang die met toepassing van een gedoogbeschikking onder de Ow zullen worden aangelegd en in stand gehouden.

Een in werking getreden gedoogbeschikking legt dus gedoogverplichtingen op aan de rechthebbende(n), maar brengt ook wijzigingen mee in de privaatrechtelijke rechtstoestand.

\section{- Wettelijke vereisten}

Het huidige wettelijke systeem kent een aantal vereisten waaraan moet zijn voldaan om aan een initiatiefnemer een gedoogbeschikking te verlenen. Zo geldt onder de BP het concessie- en/of erkenningsvereiste en moet er sprake zijn van een openbaar werk van algemeen nut. Daarnaast dient aantoonbaar minnelijk overleg te zijn gevoerd dat niet tot overeenstemming heeft geleid, en gelden twee inhoudelijke criteria ter bescherming van de rechthebbende:

- De belangen van de rechthebbende vorderen redelijkerwijs geen onteigening.

- De belemmering mag niet groter zijn dan nodig voor de aanleg en instandhouding van het werk.

Deze vereisten zijn (al dan niet met zoveel woorden) overgenomen in de Ow, waarbij art. 10.11 Ow de kernbepaling vormt. Ingevolge deze bepaling kan de minister een gedoogbeschikking verlenen indien

'voor een werk van algemeen belang:

a. voor bepaalde of onbepaalde tijd gebruik moet worden gemaakt van een onroerende zaak, en

b. met de rechthebbende op de onroerende zaak ondanks een redelijke poging daartoe geen schriftelijke overeenstemming is bereikt over het gebruik daarvan, en

14 Voor werken die wél met zoveel woorden zijn genoemd in art. 5:20 lid 2 BW volgt de doorkruising van de leer van de verticale natrekking naar onze mening reeds uit art. 5:20 lid $2 \mathrm{BW}$, ook voor zover die werken worden aangelegd en in stand gehouden krachtens een gedoogbeschikking. c. het gebruik van de onroerende zaak niet meer zal worden belemmerd dan redelijkerwijs nodig is, en

d. de belangen van de rechthebbende redelijkerwijs onteigening niet vorderen.'

De verhouding tussen onteigeningsbevoegdheid en de bevoegdheid een gedoogbeschikking te verlenen bespreken wij in paragraaf 3 . In deze paragraaf bespreken we de andere vereisten, zoals deze zijn verankerd in het huidige wettelijke systeem en zoals deze terugkeren onder de Ow.

\section{Algemeen belang}

In de eerste plaats volgt uit art. 10.11 Ow dus dat een gedoogbeschikking uitsluitend kan worden verleend voor een werk van algemeen belang. Het is vaste rechtspraak dat het algemeen belang is gegeven indien het werk in een omgevingsrechtelijk besluit is ingepast. De Ow legt echter geen koppeling tussen een gedoogbeschikking en een omgevingsplan, projectbesluit of ander omgevingsrechtelijk besluit. Het algemeen belang kan dus ook gegeven zijn zonder omgevingsrechtelijke inpassing van het werk. In de meeste gevallen wordt verondersteld dat het algemeen belang aanwezig is en in een enkel geval moet dat nader worden gemotiveerd. Die motivering kan de bestuursrechter desgevraagd toetsen.

Gebruik voor bepaalde of onbepaalde tijd

Het wettelijke vereiste dat het nodig moet zijn om voor bepaalde of onbepaalde tijd gebruik te maken van grond lijkt voor zich te spreken. Als die noodzaak niet zou bestaan, is er immers geen reden een gedoogbeschikking te verlenen. Toch volgen uit de rechtspraak op dit punt soms verrassende oordelen. Zo oordeelde het gerechtshof Amsterdam dat voor de overdraai van een windturbine over een buurperceel een gedoogplicht op dat buurperceel moest worden opgelegd, ${ }^{15}$ en oordeelde de rechtbank Oost-Brabant dat kabels op grote diepte geen inbreuk op het eigendomsrecht van een opstalhouder opleverden. ${ }^{16}$

Minnelijk overleg

Initiatiefnemers maken bij minnelijk overleg in het kader van de BP in veel gevallen gebruik van eigen modelovereenkomsten en bijbehorende algemene voorwaarden. Voor rechthebbenden bestaat dan weinig ruimte om maatwerkafspraken te maken. Verder doen initiatiefnemers vaak aanbiedingen voor schadeloosstelling aan de hand van de zogenoemde Gasunie-tarievenlijst. De Gasunie-tarievenlijst kwam tot voor kort (bijna) elk jaar in overleg tussen Gasunie en LTO Nederland tot stand en bevatte standaardtarieven voor het bepalen van de schade door de aanleg en instandhouding van het werk. Vergoedingen waren afhankelijk van het ruimtebeslag van het werk, het werkterrein en eventuele aanwezige gewassen. Verder kon ook toekomstschade

Rb. Oost-Brabant 24 april 2021, ECLI:NL:RBOBR:2021:1816. 
(schade die bij het sluiten van de overeenkomst nog niet bekend was) voor vergoeding in aanmerking komen. Tegenwoordig bevat de officiële Gasunie-tarievenlijst slechts tarieven voor gewassenschade, maar initiatiefnemers maken in de praktijk nog vaak gebruik van (eigen) tarievenlijsten om ook voorstellen te doen voor de overige vergoedingen. Het aanbieden van standaardvergoedingen is praktijk. Daarmee worden perceelsgewijze taxaties voorkomen.

De bestuursrechter toetst het minnelijk overleg in het kader van de BP terughoudend, zo blijkt uit bestendige rechtspraak. Als het aankomt op de beoordeling van een gedoogbeschikking waartegen beroep is ingesteld, stelt de bestuursrechter slechts de eis dat de minister zich bij de beoordeling van het gedoogverzoek ervan dient te vergewissen 'dat een serieuze en redelijke poging is ondernomen om langs minnelijke weg tot overeenstemming te komen'. In het kader van deze vergewisplicht dient de rechter 'te onderzoeken of de voorstellen tot vergoeding niet op voorhand als onwerkelijk en onredelijk moeten worden aangemerkt'. ${ }^{17}$ Verder gaat de toets niet. De hoogte van de aangeboden schadeloosstelling is voor de bestuursrechter niet van betekenis. Het heeft dus voor de rechthebbende geen zin om de inhoud van het overleg bij de bestuursrechter ter discussie te stellen, tenzij ieder weldenkend mens (dus ook een rechter) in één oogopslag ziet dat een 'onredelijk en op voorhand onwerkelijk' voorstel is gedaan. Dat summiere toetsingskader verklaart ook dat de bestuursrechter een gedoogbeschikking niet vernietigt indien in het kader van het minnelijk overleg door de initiatiefnemer (slechts) aanbiedingen zijn gedaan op basis van een modelovereenkomst. ${ }^{18}$ De bestuursrechter vernietigt een gedoogbeschikking evenmin op de grond dat de initiatiefnemer uitsluitend bereid is om afspraken te maken voor onbepaalde tijd, of op de grond dat de initiatiefnemer uitsluitend een aanbieding doet die bij aanvaarding niet zou leiden tot een rechtspositie gelijk aan die welke ontstaat na oplegging van de gedoogplicht. ${ }^{19}$ De toets van het minnelijk overleg is dus zeer terughoudend.

Bedacht moet worden dat de toets door de bestuursrechter slechts plaatsvindt in het kader van de beoordeling of de minister (of ander bevoegd gezag) de gedoogbeschikking mocht verlenen. Dat de bestuursrechter een gedoogbeschikking in stand laat, zegt dus niets over de redelijkheid van de minnelijke aanbiedingen van de initiatiefnemer. De bestuursrechter is niet bevoegd om zich inhoudelijk uit te laten over de redelijkheid (en rechtmatigheid) van het aanbod van de initiatiefnemer en de houding van partijen die onderhandelingen voeren. ${ }^{20}$ Als partijen daarover een geschil krijgen, is de

17 ABRvS 14 maart 2018, ECLI:NL:RVS:2018:833.

18 Rb. Amsterdam 14 juli 2021, ECLI:NL:RBAMS:2021:3655; zie ook ABRvS 14 maart 2018, ECLI:NL:RVS:2018:833, r.o. 2.3.

19 ABRvS 14 maart 2018, ECLI:NL:RVS:2018:833.

20 ABRvS 17 mei 2017, ECLI:NL:RVS:2017:1285, r.o. 5.1, waar de Afdeling o.a. overweegt: '(...) Gezien de terughoudende toets op dit punt hoeft de minister niet te treden in de inhoudelijke beoordeling van de voorwaarden. Daartoe is de civiele rechter aangewezen. (...).' burgerlijke rechter exclusief bevoegd. Dat geldt dus niet alleen voor een discussie over de omvang van de schade, maar ook als partijen verdeeld zijn over de inhoud van de te sluiten overeenkomsten en de opstelling van de initiatiefnemer bij de onderhandelingen. ${ }^{21}$

In de Ow is het minnelijk overleg wederom een toetsingscriterium. Uit art. 10.11 sub b Ow volgt dat de initiatiefnemer een redelijke poging moet hebben ondernomen om minnelijke overeenstemming te bereiken met rechthebbenden, ter voorkoming van de oplegging van de gedoogplicht. Uit de memorie van toelichting blijkt dat voor de beoordeling aansluiting moet worden gezocht bij overwegingen van de Kroon in het kader van onteigeningsprocedures: er moet sprake zijn geweest van een redelijke maar vruchteloos gebleken poging om tot minnelijke overeenstemming te komen. ${ }^{22}$ Die vergelijking gaat echter slechts beperkt op. Uit de memorie van toelichting blijkt namelijk ook dat de hiervoor geschetste bestuursrechtelijke jurisprudentie over het minnelijk overleg onverminderd van betekenis blijft.

Uiteindelijk kan die bestendige rechtspraak zo worden uitgelegd dat het voor netbeheerders ter verkrijging van een gedoogbeschikking voldoende lijkt te zijn om een rechthebbende een aantal keren te benaderen en daarbij een aanbod te doen gebaseerd op een modelovereenkomst en de schadeloosstelling te berekenen aan de hand van standaardvergoedingen.

De wijze van beoordeling van gedoogbeschikkingen door bestuursrechters neemt echter niet weg dat de onderhandelingsverhouding tussen partijen onder omstandigheden kan meebrengen dat de initiatiefnemer rekening moet houden met, op de concrete situatie toegespitste, gerechtvaardigde belangen van de rechthebbende. Zou de initiatiefnemer dat niet doen, dan is niet de bestuursrechter, maar de burgerlijke rechter bevoegd zich daarover uit te spreken. De inhoud van de bestuursrechtelijke jurisprudentie over de vergewisplicht van de minister bindt de burgerlijke rechter niet omdat die bestuursrechtelijke jurisprudentie uitsluitend betrekking heeft op de vraag of de gedoogbeschikking in stand kan blijven, maar niet op de inhoud van het minnelijk overleg. Het is bijvoorbeeld naar onze mening niet uitgesloten dat de redelijkheid meebrengt dat partijen, ter voorkoming van een gedoogplicht(procedure) én ter voorkoming van (toekomst)schade, een zakelijk recht vestigen voor beperkte duur waarbij een periodieke gebruiksvergoeding wordt overeengekomen.

Niet meer belemmering van het gebruik dan redelijkerwijs nodig is

De voorwaarde dat het gebruik van de onroerende zaak niet meer wordt belemmerd dan redelijkerwijs nodig is, neergelegd in art. 10.11 sub c Ow, heeft volgens de memorie van toelichting uitsluitend betrekking op de aan-

Kamerstukken II 2013/14, 33 962, nr. 3, p. 524. 
legfase. ${ }^{23}$ Een gedoogbeschikking kan dus niet met succes worden bestreden door te stellen dat het werk op een minder belemmerende wijze gepositioneerd zou moeten worden (de zogenoemde tracékeuze). Indien sprake is van een tracé waarvoor een omgevingsvergunning moet worden verleend, kan de tracékeuze (afhankelijk van het benodigde type omgevingsvergunning) wel ter discussie worden gesteld in de voorbereidingsprocedure op het besluit op de vergunningaanvraag en, in geval van verlening, in beroep tegen de omgevingsvergunning.

\section{- Inhoud gedoogbeschikking en rechtsbescherming}

De Ow brengt geen verandering in de eisen waaraan een gedoogbeschikking moet voldoen. Art. 10.22 Ow omschrijft die eisen. Zo moet de onroerende zaak worden aangeduid en moet in de beschikking duidelijk, met een omschrijving en tekeningen, worden vastgelegd welk werk van algemeen belang op welke locatie dient te worden gedoogd.

In art. 10.24 tot en met 10.28 Ow zijn, net als in de BP, wettelijke bepalingen opgenomen die betrekking hebben op (en ondersteunend zijn aan) alle gedoogplichten die bij beschikking worden opgelegd, zoals een gedoogplicht voor het rooien, inkorten en snoeien van hinderlijke bomen en beplantingen en regels over het opruimen van werken en het eigendom van het werk zelf. In de gedoogbeschikking kunnen daarnaast ook nog nadere voorwaarden worden opgenomen, zowel ter bescherming van het te gedogen werk als ter minimalisering van de belemmering die de gedoogplicht meebrengt.

Onder de Ow zal, anders dan onder de BP, de bestuursrechter exclusief bevoegd zijn om gedoogbeschikkingen te toetsen. ${ }^{24}$ Aangezien art. 16.33 Ow de uniforme openbare voorbereidingsprocedure van afdeling 3.4 Awb op de voorbereiding van een gedoogbeschikking van toepassing verklaart, staat tegen een eenmaal verleende gedoogbeschikking ingevolge de Awb beroep open in twee instanties. ${ }^{25}$

\section{Onteigening versus gedoogplicht}

\subsection{Belangen vorderen geen onteigening}

Zoals ook onder de BP en de Waterwet geregeld was, mag ingevolge art. 10.11 sub d Ow een gedoogbeschikking uitsluitend worden opgelegd indien de belangen van de rechthebbende redelijkerwijs geen onteigening vorderen. grond van de BP, waarbij een scheiding is aangebracht in de bevoegdheid van de civiele gerechtshoven en de bestuursrechter, verdwijnt dus. Zie daarover ABRvS 18 januari 2000, ECLI:NL:RVS:2000:AA4603, AB 2001/81 m.nt. M. Schreuder-Vlasblom.

25 Art. 16.33a Ow sluit toepassing van de coördinatieregeling uit.

\subsection{Mate van gebruiksbeperking, percentage} ten opzichte van het totale oppervlak

In de jurisprudentie is de lijn ontwikkeld dat bij de vraag of de belangen van de rechthebbende redelijkerwijs onteigening (niet) vorderen, de mate van gebruiksbeperking een belangrijke factor is. Daarbij vindt de bestuursrechter in de praktijk van belang wat het percentage is van het grondbeslag van het werk (in de definitieve situatie) en de werkzaamheden (gedurende de aanlegfase) in relatie tot het oppervlak van het gehele perceel. Zo nam de Afdeling bestuursrechtspraak van de Raad van State (hierna: de Afdeling) enerzijds aan dat de belangen van een rechthebbende niet noodzaakten tot onteigening in een geval waarin de gedoogbeschikking leidde tot een tijdelijk grondbeslag van $6,9 \%$ van het totale grondoppervlak, ${ }^{26}$ maar anderzijds dat geen gedoogplicht bij beschikking mocht worden opgelegd in een situatie waarin die gedoogplicht ertoe zou leiden dat een rechthebbende zonder onteigening definitief 16,7\% van een aaneengesloten oppervlak kwijtraakte. ${ }^{27}$

\subsection{Bijzondere omstandigheden}

Aan deze percentages kunnen geen harde conclusies worden verbonden, aangezien in de rechtspraak tevens het criterium van bijzondere omstandigheden is ontwikkeld. Er kunnen zich bijvoorbeeld bijzondere omstandigheden voordoen op basis waarvan de belangen van de rechthebbende, ondanks een relatief beperkt grondbeslag, toch onteigening vorderen. Het lijkt erop dat de wetgever bij de totstandkoming van de Ow niet onder ogen heeft gezien dat de bestuursrechter dit criterium als apart toetsingscriterium heeft ontwikkeld, nu in de memorie van toelichting wordt overwogen dat onteigening pas in de rede ligt 'als én de omvang niet gering is én er zich bijzondere omstandigheden voordoen'. Die conclusie kan echter niet uit de stand van de rechtspraak worden getrokken, nu bijzondere omstandigheden volgens vaste jurisprudentie, ongeacht de omvang van de belemmerde oppervlakte, ook op zichzelf tot de conclusie kunnen leiden dat de belangen van de rechthebbende onteigening vorderen. ${ }^{28}$

\subsection{Onteigeningsbelang}

De wetgever legt bovendien een connectie tussen de toets ex art. 10.11 sub d Ow, namelijk de vraag of de belangen van de rechthebbende redelijkerwijs onteigening niet vorderen, en het onteigeningsbelang ex art. 11.6 Ow. Van een onteigeningsbelang als bedoeld in art. 11.6 Ow is geen sprake indien de bestaande vorm van gebruik omgevingsrechtelijk, bijvoorbeeld in het omgevingsplan, niet is uitgesloten. In de memorie van toelichting is opgemerkt dat het onteigeningsinstrument niet kan worden ingezet wanneer het algemeen belang kan worden gediend door de uitoefening van een minder ingrijpende bevoegdheid, zoals het opleggen van een gedoog-

\footnotetext{
26 ABRvS 16 september 2015, ECLI:NL:RVS:2015:2895, r.o. 3.3

ABRvS 24 juli 2013, ECLI:NL:RVS:2013:431, r.o. 2.4.

ABRvS 12 augustus 2015, ECLI:NL:RVS:2015:2592, r.o. 15.4.
} 
plicht. In de memorie van toelichting wordt overwogen: ${ }^{29}$

'(...) in dat geval ontbreekt de noodzaak voor onteigening. Onteigening zou dan onevenredige nadelige gevolgen meebrengen voor de rechthebbende op de onroerende zaak. Het algemeen bestuursrechtelijke evenredigheidsbeginsel waarborgt dat onteigening een ultimum remedium is en staat dan een onteigening in de weg.'

De wetgever ziet de mogelijkheid tot het opleggen van een gedoogplicht dus als argument om onteigening niet te kunnen toelaten en onderstreept daarmee dat de gedoogplicht, anders dan onteigening, niet wordt beschouwd als 'ultimum remedium'. De bevoegdheid om bij beschikking een gedoogplicht op te leggen wordt beschouwd als juridische mogelijkheid om het uiterste middel van onteigening te voorkomen. Als die mogelijkheid bestaat, is voor onteigening geen plaats.

Daarmee ontwikkelt de gedoogbeschikking zich onder de Ow tot een belangrijk grondbeleidsinstrument. Daaraan ligt mede ten grondslag de hiervoor besproken, in art. 10.21 Ow geïntroduceerde vangnetbepaling, waardoor de gevallen waarin een gedoogbeschikking kan worden verkregen aanzienlijk zijn verruimd.

\subsection{Meervoudig grondgebruik}

Illustratief zijn de overwegingen in de memorie van toelichting met het voorbeeld van een te realiseren tunnel, waarbij het gebruik op maaiveld niet (noemenswaardig) wijzigt: ${ }^{30}$

'Dat de onteigening in de voorgestelde regeling in alle gevallen betrekking heeft op de onroerende zaak als geheel, houdt ook in dat met de voorgestelde regeling geen mogelijkheid wordt geïntroduceerd om, bijvoorbeeld voor de aanleg van een te boren tunnel, te kunnen onteigenen voor de vestiging van een opstalrecht. Zo'n regeling zou inhouden dat in de situatie dat de aanleg van het werk niet of nauwelijks een beperking van de gebruiksmogelijkheden van de eigenaar tot gevolg zou hebben, met de onteigening niet de eigendom van de onroerende zaak op de onteigenaar overgaat, maar dat alleen voor de aanlegger van het werk een opstalrecht wordt afgedwongen op de onroerende zaak die het eigendom blijft van de oorspronkelijke eigenaar. Voor zo'n regeling bestaat volgens de regering geen noodzaak, omdat een vergelijkbaar resultaat kan worden bereikt met het opleggen van een gedoogplicht op grond van de Omgevingswet.

Deze gedoogplicht kan aan een rechthebbende op een onroerende zaak worden opgelegd voor het tot stand brengen van een aantal in de Omgevingswet opgesomde werken of activiteiten en ook voor overige werken of activiteiten van algemeen belang wan- neer het belang van de openbare veiligheid, het belang van het beschermen van de fysieke leefomgeving, zwaarwegende economische belangen of zwaarwegende andere maatschappelijke belangen dit rechtvaardigen. De Omgevingswet maakt daarbij mogelijk dat door horizontale natrekking de eigendom van het werk bij de aanlegger komt te liggen. Omdat bij de besluitvorming over deze gedoogplicht onder andere moet worden afgewogen of de belangen van de rechthebbende redelijkerwijs geen onteigening vorderen, is de verhouding tussen beide instrumenten bovendien voldoende gewaarborgd.'

De wetgever houdt dus vast aan de in de jurisprudentie ontwikkelde maatstaf dat van betekenis is in welke mate het gebruik van het perceel beperkt wordt. Hij stelt bovendien niet ter discussie dat ingrijpende vormen van meervoudig grondgebruik niet behoeven te leiden tot een onteigeningsnoodzaak, zolang het bestaande gebruik in belangrijke mate mogelijk blijft.

Daarmee zet de wetgever in op een breuk met de trend dat voor ingrijpende fysieke ingrepen, zoals een te boren tunnel, tot op heden steeds - bij gebreke van overeenstemming over de vestiging van zakelijke rechten het onteigeningsinstrument is gehanteerd. ${ }^{31}$

\subsection{Onteigeningsbeschikking of gedoogbeschikking}

Niet uit het oog mag worden verloren dat (andersom) de onteigeningsbevoegdheid blijft bestaan, indien de onteigenaar het onteigeningsbelang deugdelijk motiveert. Daarbij dient de onteigenaar zoals toegelicht expliciet te betrekken of de oplegging van een gedoogplicht bij beschikking tot hetzelfde (uitvoerings)resultaat kan leiden.

De vraag werpt zich op of de overheid nog een vrije keuze heeft. Onder het huidige recht wordt dat wel aangenomen, maar de hiervoor opgenomen citaten uit de memorie van toelichting bij de Ow suggereren dat onder de Ow geen onteigeningsbelang mag worden aangenomen indien het beoogde resultaat niet of nauwelijks leidt tot een beperking van de gebruiksmogelijkheden van de rechthebbende en zonder grondverwerving door middel van een gedoogplicht bij beschikking kan worden gerealiseerd op een wijze die vergelijkbaar is met het resultaat dat kan worden bereikt indien de overheid de gronden in eigendom zou hebben.

Zo lijkt de door de wetgever gevolgde koerswijziging ook gevolgen te hebben voor de grondpraktijk bij waterschappen. Waterschappen plegen bij dijkversterkingen uit het oogpunt van doelmatigheid en maximale controle veelal het onteigeningsinstrument te hanteren, ook in situaties waarin (bijvoorbeeld: agrarisch) medegebruik mogelijk blijft. De Kroon aanvaardt dat, ${ }^{32}$ maar het lijkt

31 Zie bijv. HR 27 oktober 2006, ECLI:NL:HR:2006:AY8277 (onteigening ten behoeve van de ondergrondse tunnel van de HSL-Zuid onder het Groene Hart) en KB 27 juni 2016, Stcrt. 2016, 29237 (onteigening ondergrondse tunnel Rijnlandroute).

32 KB 28 oktober 2010, Stcrt. 2010, 17057 (dijkversterking Bergambacht). 
erop dat de wetgever onder de Ow de strengere lijn wil volgen dat alleen sprake is van een onteigeningsbelang voor dijkversterking indien het bestaande gebruik (permanent) onmogelijk wordt gemaakt en door middel van een gedoogbeschikking de beoogde wijze van dijkversterking niet kan worden bereikt.

Naar onze mening is de praktijk niet gediend met deze koerswijziging. Wij komen daar in paragraaf 6 op terug.

\subsection{Belangenafweging ingekaderd}

In een onteigeningsbeschikking moet worden gemotiveerd dat het beoogde resultaat niet met een minder ingrijpende bevoegdheid kan worden bereikt. De wetgever merkt de gedoogbeschikking aan als een minder ingrijpende bevoegdheid. Anderzijds moet in een gedoogbeschikking worden gemotiveerd dat de belangen van de rechthebbende redelijkerwijs geen onteigening vorderen.

Van een vrije belangenafweging is als gevolg van de tot op heden ontwikkelde jurisprudentie geen sprake, omdat de toets of de belangen van de rechthebbende onteigening vorderen, zich toespitst op het grondbeslag en eventuele bijzondere omstandigheden. De wens van een eigenaar lijkt dus niet van betekenis te zijn, hoe redelijk die wens naar objectieve maatstaven ook kan zijn. Het is immers goed denkbaar dat een eigenaar naar objectieve maatstaven gegronde redenen heeft om zijn positie als eigenaar van belemmerde grond niet te willen behouden indien zijn eigendom wordt belast met een gedoogplicht voor een ondergrondse tunnel voor gemotoriseerd verkeer, een ondergrondse 'leidingenstraat' of een bovengronds hoogspanningsschakelstation.

\section{Schade}

\subsection{Vergoedingsplichtige}

Zowel onder het huidige recht als onder de Ow is de initiatiefnemer (ofwel: de houder van de gedoogbeschikking) de partij waarop de verplichting rust de schade te vergoeden. In de praktijk is dat de eigenaar van het te gedogen werk, bijvoorbeeld de leidingbeheerder.

\subsection{Bevoegde rechter}

In afdeling $15.2 \mathrm{Ow}$ is de wettelijke regeling opgenomen over schadeloosstelling bij gedoogplichten. Voor alle schades is de burgerlijke rechter bevoegd. In beginsel is de gewone burgerlijke rechter bevoegd: de sector civiel van de rechtbank. Anders dan onder de BP is dus niet langer sprake van een exclusieve bevoegdheid van de kantonrechter. De kantonrechter is alleen nog bevoegd indien de vordering niet meer beloopt dan $€ 25.000$ (art. 93 Wetboek van Burgerlijke Rechtsvordering (Rv)).

\subsection{Schade bij gedoogplichten van rechtswege: aftrek normaal maatschappelijk risico}

Voor de gedoogplichten van rechtswege geldt ingevolge art. $15.13 \mathrm{Ow}$ dat schade uitsluitend voor vergoeding in aanmerking komt indien deze boven het normaal maatschappelijk risico uitstijgt en de gedoogplichtige in vergelijking met anderen onevenredig zwaar wordt getroffen.

\subsection{Schade bij gedoogbeschikkingen: volledige vergoeding}

Voor de meer ingrijpende, bij beschikking opgelegde gedoogplichten geldt ingevolge art. 15.14 Ow daarentegen het uitgangspunt dat schade die een rechtstreeks en noodzakelijk gevolg is van de opgelegde gedoogplicht, voor volledige vergoeding in aanmerking komt. Daarmee is aansluiting gezocht bij de rechtspraktijk zoals deze zich heeft ontwikkeld onder de BP. Anders dan onder de huidige Waterwet het geval is, geldt het beginsel van een volledige schadeloosstelling onder de Ow ook voor gedoogplichten die door het dagelijks bestuur van een waterschap worden opgelegd. Daarbij past de nuancering dat de bestuursrechter in de praktijk ook voor deze gedoogplichten al uitging van een volledige schadeloosstelling indien de onroerende zaak zelf wordt aangetast. ${ }^{33}$

Er mag dus van worden uitgegaan dat de ontwikkelde rechtspraak over de volledige vergoeding van schade veroorzaakt door bij beschikking opgelegde gedoogplichten, die wij hierna bespreken, onverkort van toepassing blijft.

\subsection{Schadevergoeding, telkens wanneer zich} nieuwe schade voordoet

De Hoge Raad overwoog in 1963: $:^{34}$

'(...) dat aangezien de verplichting de instandhouding van het aangelegde werk te gedogen zich uitstrekt over de periode waarin dat werk in stand wordt gelaten, van schade gedurende het gehele verloop van die periode zal kunnen blijken;

dat uit de geschiedenis van de totstandkoming van de wet, waarbij werd teruggegrepen op de geschiedenis van de totstandkoming van de verwante Telegraaf- en Telefoonwet 1903, blijkt dat ook de wetgever zich de afwikkeling van de schadevergoeding niet aldus heeft voorgesteld dat deze, zoals bijvoorbeeld geschiedt bij de toepassing van de Onteigeningswet, eens en voorgoed wordt vastgesteld naar den op een bepaald tijdstip bestaanden toestand met inachtneming van alle op dat tijdstip bestaande omstandigheden en waardering van alle met meer of minder zekerheid bepaalbare vooruitzichten, doch er van is uitgegaan dat zowel bij den aanleg als daarna van schade blijken kan en dat van elke schade, waarvan gedurende den tijd waarin het werk in stand blijft, blijkt, telkens, wanneer zij blijkt, de vergoeding kan worden gevorderd; (...).'

ABRvS 19 juni 2013, ECLI:NL:RVS:2013:CA3668, r.o. 4, waar wordt verwezen naar de wetsgeschiedenis (Kamerstukken II 2006/07, 30 818, nr. 3).

34 HR 6 december 1963, ECLI:NL:HR:1963:AB3973, NJ 1965/56. 
De rechthebbende heeft dus aanspraak op vergoeding van schade, elke keer wanneer zich schade voordoet die nog niet eerder is vergoed. Aangezien, anders dan bij onteigening, zich in de toekomst opnieuw schade kan voordoen, is het essentieel dat precies wordt vastgelegd op welke schadeposten een vergoeding ziet.

\subsection{Waardevermindering}

Ook indien een gedoogplicht leidt tot een waardevermindering is sprake van schade die voor vergoeding in aanmerking komt. ${ }^{35}$ De waardevermindering moet dan wel kunnen worden aangetoond. ${ }^{36}$ Die voorwaarde vormt in de praktijk bij agrarische gronden soms een probleem, bijvoorbeeld indien op zichzelf niet ter discussie staat dat de agrarische bewerkingsmogelijkheden van stroken grond boven of onder een leiding door een gedoogplicht worden belemmerd, maar deze belemmering in de vrije markt niet (kenbaar) wordt verdisconteerd in (agrarische) verkoopprijzen, wat het lastig te taxeren maakt. De rechter kan geen schade begroten indien de omvang van de waardevermindering nog te onzeker is, ${ }^{37}$ maar niet uitgesloten is dat aan de rechthebbende een voorschot wordt toegekend. ${ }^{38}$

In 2019 heeft de Hoge Raad nogmaals bevestigd dat waardevermindering die aantoonbaar haar oorzaak vindt in een bij beschikking opgelegde gedoogplicht voor volledige vergoeding in aanmerking komt. Dat wordt niet anders indien de waardevermindering mede haar oorzaak vindt in het aan de gedoogbeschikking voorafgegaan omgevingsrechtelijk besluit tot planologische inpassing van het te gedogen werk. ${ }^{39}$

Het oordeel van de Hoge Raad betekent dat de gedoogplichtige die meent dat zijn perceel door de te gedogen werken of werkzaamheden in waarde is gedaald, zich steeds rechtstreeks tot de initiatiefnemer van het te gedogen werk kan wenden en - voor zover de waardevermindering is veroorzaakt door de gedoogplicht ${ }^{40}$ - geen risico loopt om tegengeworpen te krijgen dat de schade (slechts) het gevolg is van planologisch nadeel.

4.7 Initiatief bij gedoogplichtige rechthebbende Een vordering tot vergoeding van schade kan worden afgewezen indien deze niet of onvoldoende concreet is. Anders dan in het onteigeningsprocesrecht ligt het initiatief om concrete schade vergoed te krijgen bij de

35 HR 22 mei 1970, ECLI:NL:HR:1970:AB5597, NJ 1970/368.

36 HR 2 februari 1979, ECLI:NL:HR:1979:AB7302, NJ 1979/384.

37 Concl. A-G M.H. Wissink, ECLI:NL:PHR:2019:453, bij HR 21 juni 2019, NJ 2019/447 m.nt. E.W.J. de Groot, overweging 2.7.2 over het hiervoor besproken arrest van 6 december 1963.

38 Vgl. HR 19 juli 2019, ECLI:NL:HR:2019:1278, r.o. 2.11.7-2.11.8 (beantwoording prejudiciële vragen aardbevingsschade Groningen).

39 HR 21 juni 2019, ECLI:NL:HR:2019:996, NJ 2019/447 m.nt. E.W.J. de Groot, TBR 2019/115 m.nt. J.A.M.A. Sluysmans, TvAR 2019/8002, UDH:TvAR/15782 m.nt. W.J.E. van der Werf, Jurisprudentie Grondzaken 2019/201 en 2019/202 m.nt. F.M.A. van der Loo.

40 Bij een leidingtracé moet dus steeds onder ogen worden gezien of schade uitsluitend voortvloeit uit de leiding, voor zover deze aanwezig is op het eigen perceel, of dat de schade (mede) voortvloeit uit de aanwezigheid van de leiding (of bijv. een mast) buiten het perceel van de gelaedeerde. rechthebbende. Daarmee rust op de rechthebbende dus de bewijslast dat de schade zich heeft voorgedaan en dat sprake is van causaal verband tussen de gedoogplicht en de schade. De rechthebbende moet dit concreet maken. Dat sluit overigens niet uit dat rechthebbende de burgerlijke rechter kan verzoeken om een of meer deskundigen te benoemen die de rechter adviseren over de omvang van de schade.

\subsection{Rechtsingang}

Geconstateerd moet worden dat de toegang tot de rechter minder optimaal is dan in een onteigeningsprocedure. Dat verschil wijzigt niet onder de Ow.

Anders dan in het onteigeningsprocesrecht is in geval van een gedoogplicht geen sprake van een 'automatische' procedure waarin de schadeloosstelling wordt vastgesteld. Als de gedoogplicht eenmaal op een perceel rust, is het dus van de rechthebbende afhankelijk of eventuele schade wordt gevorderd. In de praktijk zal daarbij voor de rechthebbende een afweging zijn of en in hoeverre de schade en het causale verband tussen de gedoogbeschikking en de schade bewezen kunnen worden.

In het onteigeningsprocesrecht spelen daarentegen causaliteitsdiscussies geen rol, en staat een passieve houding van de onteigende niet in de weg aan de bepaling van een voorlopig schadebedrag (voorafgaande aan de eigendomsovergang) en vervolgens aan de bepaling van de definitieve schadeloosstelling. Ook indien de onteigende daarover geen standpunt inneemt, stelt de rechter deze schadeloosstelling - na advisering door een deskundigencommissie - zelfstandig vast. ${ }^{41}$

Daarnaast ontbreekt in schadeloosstellingsprocedures die voortvloeien uit gedoogbeschikkingen, anders dan in het onteigeningsprocesrecht, een wettelijke bepaling op basis waarvan de kosten van een door de rechthebbende in te schakelen advocaat en/of (andere) deskundige voor volledige vergoeding in aanmerking komen. De rechthebbende is onder de Ow aangewezen op art. 6:96 BW. Daaruit volgt dat de redelijke kosten ter vaststelling van schade en aansprakelijkheid en de redelijke kosten ter verkrijging van voldoening mede als vermogensschade voor vergoeding in aanmerking komen. ${ }^{42}$

\section{Gebruiksvergoeding commerciële leidingen}

Zoals hiervoor al kort aangestipt, introduceert de Ow een gebruiksvergoedingsregeling in art. 13.3e. In bepaalde gevallen moeten initiatiefnemers van gedoog-

41 Zie bijv. HR 9 juni 2017, ECLI:NL:HR:2017:1069, TvAR 2017/5904, UDH:TvAR/14600 m.nt. W.J.E. van der Werf.

42 Naar onze mening strekt deze dubbele redelijkheidstoets zich ook uit tot noodzakelijkerwijs gemaakte proceskosten ter verkrijging van de (volledige) schadevergoeding. Onder de Waterwet was echter slechts ruimte voor een forfaitaire proceskostenvergoeding krachtens het Besluit proceskosten bestuursrecht. 
plichten een redelijke gebruiksvergoeding aan rechthebbenden gaan betalen. Deze regeling is het gevolg van een amendement van de Tweede Kamerleden Bisschop en Ronnes. ${ }^{43}$ Uit de toelichting bij het amendement blijkt dat toename van commerciële belangen (ten opzichte van het algemeen belang) bij de aanleg of wijziging van werken waarvoor een gedoogplicht kan worden aangevraagd, de reden voor dit amendement is geweest. Bisschop en Ronnes (en met hen een Kamermeerderheid) vinden het in dat licht gerechtvaardigd dat een eigenaar van een onroerende zaak niet alleen aanspraak kan maken op een schadevergoeding, maar ook op een gebruiksvergoeding.

De Ow en bijbehorende ministeriële regeling bepalen de gevallen waarin aanspraak op een gebruiksvergoeding kan worden gemaakt, welke rechthebbenden dat kunnen doen en hoe die gebruiksvergoeding moet worden berekend. Relevant zijn hoofdstuk 10 Ow, afdeling 13.2 en 15.2 Ow en afdeling 14.2 Omgevingsregeling.

\subsection{Soorten gedoogplichten en initiatiefnemers} In art. 13.3e lid $1 \mathrm{Ow}$ is vastgelegd voor welk soort (bij beschikking op te leggen) gedoogplicht een gebruiks-vergoeding aan rechthebbenden moet worden betaald: het gaat om gedoogplichten voor energie- en mijnbouwwerken (art. 10.14 Ow) en gedoogplichten voor andere werken van algemeen belang waarin de $\mathrm{Ow}$ niet specifiek heeft voorzien (art. 10.21 Ow, de hiervoor besproken vangnetbepaling). Voor andere typen gedoogplichten voorziet de Ow vooralsnog niet in een gebruiksvergoedingsregeling.

Andersom is in art. 13.3e lid 1 Ow vastgelegd welke initiatiefnemers niet voor de betaling van een gebruiksvergoeding kunnen worden aangesproken: initiatiefnemers die zijn aangewezen als netbeheerder en in beginsel geen commercieel belang bij hun netten hebben, zijn uitgezonderd.

Onder aangewezen netbeheerders worden verstaan zij die zijn aangewezen in de Elektriciteitswet 1998, de Gaswet of de Warmtewet. Denk aan partijen als TenneT, Gasunie, Eneco en overige elektriciteits-, gas- en warmtebedrijven. Verder zijn bestuursorganen (althans de rechtspersonen waartoe zij behoren) als bedoeld in de Awb ook van de betaling van gebruiksvergoedingen uitgezonderd. Gedachte achter deze algemene uitzondering is, zo blijkt uit de toelichting op het amendement, dat op deze netbeheerders bepaalde regelgeving van toepassing is. Zij hebben te maken met tariefregulering, toezicht en publiek aandeelhouderschap, hetgeen naar de mening van de wetgever in de weg zou kunnen staan aan een afgedwongen gebruiksvergoeding.

Uit de toelichting op het amendement blijkt verder dat met name wordt gedacht aan initiatieven voor de aanleg en instandhouding van leidingen voor koelwater, voor

43 Kamerstukken II 2018/19, 34 986, nr. 50 (amendement Bisschop/Ronnes). zoutwinning en voor een gasproductienet (niet te verwarren met een gas(product)net!). Uit de toelichting op de Aanvullingsregeling grondeigendom Omgevingswet blijkt de aanleg van een windmolenpark ook onder de regeling te kunnen vallen. ${ }^{44}$ Ten slotte kan worden gedacht aan initiatieven voor (andere) energie- en mijnbouwwerken die niet onder de uitzondering als hiervoor genoemd vallen, zoals initiatieven voor CO2-opslag.

\subsection{Rechthebbenden}

Voor de inkadering van de gebruiksvergoedingsregeling is verder relevant welke partijen initiatiefnemers kunnen aanspreken voor betaling van een dergelijke vergoeding. De wet spreekt over 'de rechthebbende'. Voor de definitie van dit begrip moet worden gekeken naar de algemene begripsbepaling voor gedoogplichten in art. 10.1 Ow: 'degene die enig recht heeft op de onroerende zaak waarin, waarop, waarboven of waaronder (a) activiteiten (...) worden verricht, of (b) een werk van algemeen belang tot stand worden gebracht of opgeruimd'.

Deze begripsbepaling is ruimer gedefinieerd dan die in het amendement van Bisschop en Ronnes. Waar het amendement nog spreekt van 'de eigenaar van de betreffende onroerende zaak (de rechthebbende)', wordt met de algemene begripsbepaling een ruimere kring van rechthebbenden onder de werking van de gebruiksvergoeding geschaard. Naast (grond)eigenaren kan bijvoorbeeld worden gedacht aan erfpachters, opstalhouders, pachters en (vrucht)gebruikers.

Hoewel vanuit de praktijk bij de totstandkoming van de ministeriële regeling is gepleit voor het beperken van de kring van rechthebbenden, is het begrip in de definitieve regeling ${ }^{45}$ onverminderd ruim gebleven. 'Een ieder die enig recht heeft op de onroerende zaak waarop de gedoogplicht rust', heeft een wettelijk recht op het ontvangen van een gebruiksvergoeding. De verdeling van de vergoeding over de rechthebbenden hangt af van de omstandigheden van het geval, zoals de aard van het (beperkte) recht, de specifieke situatie ter plaatse en de verhouding ('hoe omvattend', het aantal vierkante meters) tussen het gebruiksrecht en het eigendomsrecht.

De gebruiksvergoeding die aan andere rechthebbenden dan de grondeigenaar wordt betaald, wordt in mindering gebracht op het bedrag dat laatstgenoemde ontvangt.

\subsection{Gebruiksvergoeding versus schadevergoeding}

Ander belangrijk aandachtspunt bij de vraag of een recht op een gebruiksvergoeding bestaat, is de vraag of

44 Regeling van de Minister van Binnenlandse Zaken en Koninkrijksrelaties en de Minister van Landbouw, Natuur en Voedselkwaliteit van 29 juni 2021 tot wijziging van de Omgevingsregeling vanwege het opnemen van regels over landinrichting, onteigening en kostenverhaal en tot wijziging en intrekking van enige andere regelingen (Aanvullingsregeling grondeigendom Omgevingswet (Stcrt. 2021, 34636)), p. 111

45 Idem, p. 113. 
deze niet al is inbegrepen bij de schadevergoeding die de rechthebbende ontvangt.

Voor gedoogplichten van rechtswege en voor die op te leggen bij beschikking moet de initiatiefnemer gevolgschade aan rechthebbenden vergoeden. In het kader van gedoogplichten bij beschikking betreft dat een volledige schadevergoeding, die alle rechtstreekse en noodzakelijke gevolgschade moet dekken. Als aan een rechthebbende méér wordt betaald dan waar hij op grond van art. 15.4 Ow recht op heeft, dan wordt de gebruiksvergoeding (afhankelijk van de hoogte van de extra vergoeding) geacht daarbij te zijn inbegrepen. In dat geval kan geen separaat beroep op art. 13.3e Ow meer worden gedaan, zo blijkt uit de eerste volzin van lid 1 van laatstgenoemd artikel.

In het kader van minnelijk overleg voorafgaand aan de oplegging (en ter voorkoming) van een gedoogbeschikking kunnen partijen desalniettemin een hoger bedrag overeenkomen dan waar de wet hen toe verplicht. Daarbij kan worden gedacht aan een hoger bedrag dan de uitkomst van de hierna gespecificeerde berekeningswijze van de gebruiksvergoeding, maar ook aan een geval waarin de betaling van een gebruiksvergoeding op grond van de wet niet verplicht is.

\subsection{Berekening gebruiksvergoeding}

In de definitieve ministeriële regeling is de berekening van de gebruiksvergoeding onveranderd gebleven. De berekening vindt plaats aan de hand van de formule:

gebruiksvergoeding = grondoppervlakte * grondwaarde * rendementsfactor.

Onder grondoppervlakte wordt verstaan het aantal vierkante meters (van een of meerdere percelen) waarop de gedoogplicht rust. Onder grondwaarde wordt de actuele marktwaarde van het perceel verstaan, op basis van het toegelaten planologisch gebruik de dag voorafgaand aan oplegging van de gedoogplicht. Voor de rendementsfactor wordt gerekend met een forfaitair rendement van $2 \%$.

Met andere woorden: bij de berekening is het aantal vierkante meters dat wordt belemmerd van belang, wordt enkel gekeken naar de marktwaarde voorafgaand aan de oplegging van de gedoogplicht (de gedoogplicht wordt 'weggedacht') en wordt gerekend met een verondersteld rendement, gebaseerd op de pachtnormen. Uitgangspunt is dat de gebruiksvergoeding jaarlijks aan de rechthebbende(n) wordt betaald. Partijen kunnen overeenkomen om de gebruiksvergoeding in één keer of voor een langere periode af te kopen. De ministeriële regeling voorziet ook in een regeling voor indexatie van de grondwaarde: dat gebeurt elke vijf jaar aan de hand van de consumentenprijsindex.

Voor geschillen over de hoogte van de gebruiksvergoeding is de burgerlijke rechter bevoegd. De rechter kan een oordeel geven over de invulling en hoogte van de vergoeding. Voor het bepalen van de hoogte van de ver- goeding kan de rechter een deskundigenonderzoek gelasten. Ten slotte kan de rechter bepalen of de gebruiksvergoeding periodiek moet worden betaald of eenmalig moet worden afgekocht.

Het is de vraag in welke gevallen een eigenaar (of andere rechthebbende) voor de burgerlijke rechter de betaling van een gebruiksvergoeding zal vorderen. De rechthebbende zal de (kostbare) stap moeten zetten om de burgerlijke rechter in te schakelen. Denkbaar is dat vorderingen tot bepaling van een gebruiksvergoeding (al dan niet bij wijze van alternatief) worden meegenomen in procedures waarin schadevergoedingen worden gevorderd.

\subsection{Gebruiksvergoeding in de praktijk}

Hoe groot de impact van de introductie van de gebruiksvergoedingsregeling op de praktijk zal zijn, valt nog te bezien. In voorbereiding op de ministeriële regeling is onderzoek gedaan naar de uitwerking en impact van de regeling. Daarvoor zijn onder meer de opgelegde gedoogplichten in de periode 1 januari 2015 tot en met 9 oktober 2019 onderzocht, waaruit is gebleken dat slechts één gedoogplicht onder de werking van de nieuwe regeling zou zijn gevallen.

Wel kunnen wij ons voorstellen dat de introductie van de gebruiksvergoedingsregeling niet alleen van invloed zal zijn op het minnelijk overleg dat voorafgaat aan gedoogbeschikkingen die onder de regeling vallen, maar ook op het minnelijk overleg dat voorafgaat aan gedoogbeschikkingen die niet onder de regeling vallen, omdat de regeling nu eenmaal voorziet in een formule op basis waarvan relatief eenvoudig een jaarlijkse gebruiksvergoeding kan worden betaald, waardoor in het belang van beide partijen vermogensschade - en juridische procedures daarover - kan worden beperkt en de gedoogplicht het eigendomsrecht (voor opvolgende rechthebbenden) minder negatief beïnvloedt.

\section{Conclusies en aanbevelingen}

De BP zou op 13 mei 2027 honderd jaar oud worden. De inwerkingtreding van de Ow belemmert echter die verjaardag. Gelukkig maar, want de BP sluit niet meer aan op de ruimtelijke ingrepen die in de praktijk plaatsvinden om te dienen als basis voor gedoogbeschikkingen. Het is dus goed dat de wetgeving wordt geactualiseerd.

Op het eerste gezicht lijkt de Ow voor weinig inhoudelijke verandering te zorgen. Het onderscheid tussen gedoogplichten van rechtswege en bij beschikking op te leggen blijft gehandhaafd. De vereisten voor het aanvragen van een gedoogbeschikking blijven grotendeels gelijk, met uitzondering van het vervallen van het erkennings- en/of concessievereiste. Ook op het gebied van jurisprudentie verwachten wij dat de ingezette lijn zal worden doorgezet, zowel in geval van de bestuursrechtelijke toetsing van gedoogbeschikkingen als in geval 
van de civielrechtelijke beoordeling van schades. Wel is het prettig dat de procesregels vereenvoudigd worden.

Toch blijft het daar niet bij. De nieuwe wettelijke regeling biedt immers een stevige verruiming van bevoegdheden om gedoogbeschikkingen te verlenen, in het bijzonder door de nieuwe vangnetbepaling van art. 10.21 Ow. Daarbij komt dat de wetgever de oplegging van een gedoogplicht bij beschikking minder ingrijpend vindt dan onteigening en daaraan de conclusie verbindt dat onteigening niet noodzakelijk is indien de oplegging van een gedoogplicht bij beschikking volstaat om een ontwikkeling van meervoudig grondgebruik mogelijk te maken, zonder dat het oorspronkelijke (enkelvoudige) gebruik noemenswaardig wordt belemmerd. Daarmee ontwikkelt de gedoogbeschikking zich tot een grondbeleidsinstrument voor ontwikkelingen van meervoudig grondgebruik waarbij de oorspronkelijke functie (grotendeels) behouden blijft. Een (ver)nieuw(d) grondbeleidsinstrument dat, anders dan onteigening, niet wordt beschouwd als 'ultimum remedium'.

Naar onze mening noodzaakt het door de wetgever voorgestane systeem, waarbij geen onteigeningsbelang aanwezig wordt geacht indien de toepassing van een bevoegdheid tot oplegging van een gedoogbeschikking tot een gelijk uitvoeringsresultaat kan leiden, tot een andere benadering van de bestuursrechtelijke toets of de belangen van de rechthebbende (wel of geen) onteigening vorderen. Alle belangen van de rechthebbende dienen in die belangenafweging te (kunnen) worden betrokken, waarbij ook de redelijke wens van de eigenaar (of andere rechthebbende) een rol zou moeten spelen om geen eigenaar te blijven van de belemmerde grond. Die wens kan des te gerechtvaardigder zijn indien een gedoogplicht ertoe leidt dat de eigenaar de volledige beschikkingsmacht verliest over een (relevant) deel van zijn grond. Niet goed valt in te zien waarom de belangen van de eigenaar in dat geval geen onteigening van de betreffende grond vorderen. Daarmee is direct gezegd dat de afweging in beginsel zou moeten worden toegespitst op het gedeelte van de eigendom dat daadwerkelijk door een werk worden belemmerd, omdat alleen voor dat gedeelte van de eigendom een onteigeningsbevoegdheid denkbaar is. De vraag wat de procentuele verhouding is tussen het belemmerde gedeelte en de totale aaneengesloten eigendom, lijkt ons dan ook voor de afweging of de belangen van de rechthebbende onteigening vorderen van het betreffende gedeelte, niet relevant.

Indien het bevoegd gezag alle redelijke en kenbare belangen van de rechthebbende meeweegt en bij een afweging tot de slotsom komt dat de belangen van de rechthebbende onteigening van de belemmerde grond vorderen, zou het onteigeningsbelang een gegeven moeten zijn, in afwijking van art. 11.6 Ow óók in die situatie waarin het bestaande gebruik op de belemmerde grond omgevingsrechtelijk nog - zij het, door de belemmering, beperkt - mogelijk blijft.
Naar onze mening brengt de belangrijke betekenis van een gedoogbeschikking als grondbeleidsinstrument verder met zich dat de wet geen blokkades zou mogen opwerpen voor de toegang tot de rechter. Er is immers, voor zover het gaat om verkrijging van vergoeding van schade, geen goede reden om onderscheid te maken tussen de bewijspositie van een onteigende of een gedoogplichtige partij: beide zijn aangetast in hun (eigendoms) recht en beide hebben recht op een (volledige) vergoeding van de schade die (eigendoms)aantasting veroorzaakt. Een eenvoudigere toegang tot de schaderechter zou bovendien bewerkstelligen dat de bestuursrechter minder geconfronteerd wordt met discussies over het minnelijk overleg. Dit zou worden bewerkstelligd indien wordt voorzien in een verplichte schadevaststellingsprocedure, vergelijkbaar met de verzoekschriftprocedure zoals deze in de Ow voor onteigeningen wordt geïntroduceerd, in elk geval voor die gevallen waarin partijen niet verdeeld zijn over de aanwezigheid van schade, maar wel over de omvang ervan.

Overigens zijn wij ook benieuwd naar de toekomstige praktische gang van zaken. Zo is de vraag hoe de beoordeling van gedoogverzoeken - die onder de Ow ook wordt overgelaten aan RWS CD - zich zal gaan ontwikkelen ten opzichte van onteigeningsverzoeken, die wordt overgeheveld naar onteigenaars zelf.

Actueel is de vraag hoe zal worden omgegaan met reeds bestaande netwerken waarvoor in het verleden gedoogplichten zijn opgelegd, en waarvoor de wens bestaat deze voor een ander doel aan te wenden. Denk bijvoorbeeld aan het omvormen van het aardgastransportnetwerk tot een waterstoftransportnetwerk. ${ }^{46}$ Wij menen dat rechthebbenden niet gehouden zijn om de functiewijziging van een transportnetwerk te gedogen op basis van een oude beschikking waarin uitsluitend de oorspronkelijke functie is omschreven. Het is dus nuttig om tijdig in gesprek te gaan met die rechthebbenden.

De introductie van een gebruiksvergoeding juichen wij toe. Door de (noodzakelijke) energietransitie neemt de verdiencapaciteit van de te gedogen werken toe en kunnen gedoogplichten steeds meer naast een algemeen belang (ook) een commercieel doel gaan dienen. Door aan rechthebbenden een gebruiksvergoeding te betalen dragen rechthebbenden niet enkel de lasten, maar kunnen zij ook de vruchten van een ontwikkeling plukken. Wij menen dan ook dat het verstandig is om aan de gebruiksvergoedingsregeling een bredere werking toe te kennen door sommige netbeheerders niet bij voorbaat van het betalen ervan uit te zonderen, maar telkens naar de omstandigheden van het geval te kijken. Zo kan een verbrede regeling mogelijk ook bijdragen aan het maken van afspraken over functiewijzigingen van netwerken ten behoeve van de energietransitie.

46 Zie voor actuele ontwikkelingen het onderzoek Hyway27, raadpleegbaar via www.tweedekamer.nl. 